\title{
Marxists versus Non-Marxists: Soviet Historiography in the 1920s
}

The policy of "using non-communist hands in the building of communism," almost as old as the Soviet government itself, came to an end at the outset of the First Five-Year Plan. In the early 1920s the Communist Party had come to accept the realities of a socialist regime confined to an underdeveloped country. Consequently, during the years of the New Economic Policy (192128), the party sought to guicle numerous institutions in which its members and supporters were a minority. To this end, the Communist Party created a network of scholarly institutions staffed by Marxist scholars which paralleled the traditional institutions staffed and led primarily by non-Marxist scholars. The purpose of this essay is to recount some of the conflicts between Marxist and non-Marxist historians and to make some suggestions about connections between these conflicts and ongoing political changes.

The chief center of Marxist scholarship in this period was the Communist Academy, which in 1918 had begun as little more than a discussion group and reading room, and which grew by the early 1930s into an array of research institutes, graduate seminars, commissions, societies, and so forth. Historical research was carried out in a number of the Communist Academy's divisions, but in 1925 the Society of Marxist Historians was formed within the Academy and became its center for historical research and discussion. The new society sought to guicle all Marxist historiography in and out of the Communist Academy and to contain and modify non-Marxist scholarship. ${ }^{1}$

A second important center of historical investigation, the Commission for the Study of the October Revolution and the Russian Communist Party (Istpart), was founded in 1920 as an agency to collect materials on the history of the Conmunist Party and on the October Revolution. Istpart was composed of a nationwicle network of branches and worked in close association with the Society of Old Bolsheviks. Its chief journal, Proletarskaia revoliutsiia, predecessor of Voprosy istorii KPSS, published an immense amount of primary source material and became an important vehicle for political and historical discussion. Istpart and two similar enterprises-the Marx-Engels Institute, which collected massive amounts of material on Marxism and the European labor movement, and the Lenin Institute, founded

1. See Ocherki istorii istoricheskoi nauki v SSSR, vol. 4 (Moscow, 1966), pp. 233-37. 
in 1923 and directed by L. B. Kamenev-were the components of what is today the Institute of Marxism-Leninism. ${ }^{2}$

Another important center of Marxist scholarship, that even a brief survey must note, was the Institute of Red Professors. Founded in 1921, it was an advanced school, the equivalent of a graduate center for party intellectuals, attended mostly by young Bolshevik veterans of the Civil War. It was the capstone of an elaborate network of party schools, and some important publications and even major controversies grew out of the Institute's seminars. Like the Communist Academy and the Society of Marxist Historians, the Institute of Red Professors was headed by M. N. Pokrovskii, the leading Soviet Marxist historian of the period. ${ }^{3}$ Mention should also be made of the Society of Political Convicts and Penal Exiles, composed of former members of the revolutionary movement, both Marxists and Populists. This society published the scholarly journal Katorga i ssylka.

Pokrovskii referred to the Society of Marxist Historians as his "offspring." It was not a research center but a "voluntary tribune," Pokrovskii's chief instrument for containing the influence of non-Marxist historians, and it constituted the nucleus of the "school of Pokrovskii." The Society regularly sponsored public meetings in which research findings were reported and debated. Frequently, important anniversaries were commemorated-the Decembrist Uprising, the birthday of Chernyshevskii, the 1905 and 1917 Revolutions, and so forth. Publication of the journal Istorik-marksist was also an important activity of the Society. Unlike other Soviet-Marxist historical journals of the period, Istorik-marksist did not usually publish primary source material. It was a journal of opinion. Pokrovskii regarded the Society of Marxist Historians not only as an instrument to serve Marxist scholarship through the intimidation of opponents but also to draw non-Marxist historians to the banner of Marxism. As one of his students later wrote: "The very title 'Society of Marxist Historians' drew a line of demarcation between bourgeois scholars and those who stood on Marxist positions." 4

Russian and Western scholars agree that non-Marxist historiography preempted the field in the early years of Soviet power, that is, until at least 1925. This situation prevailed even though some non-Marxist historians had been deported in 1922 along with other members of the intelligentsia, and

2. See G. D. Alekseeva, "Sozdanie tsentrov sovetskoi istoricheskoi nauki $i$ ikh deiatel'nost' v 1918-1923 gg.," in M. V. Nechkina, ed., Istoriäa i istoriki (Moscow, 1965), pp. 90-116.

3. See L. V. Ivanova, $U$ istokov sovctskoi istoricheskoi nauki: Podgotovka kadrov istorikov-marksistov 1917-1929 (Moscow, 1968), pp. 121-48.

4. A. L. Sidorov, "Nekotorye razmyshleniia o trude i opyte istorika," Istoriia SSSR, 1964, no. 3, pp. 134-35. 
despite the fact that historians often had "to purchase the right to publish." The 1920s was a distinctively creative period for the older generation of Russian scholars, one in which highly technical document analysis was combined with bold hypotheses to recast the problem of serfdom. A number of threads of scholarship-the forbidden years for the peasant movement, the Russian north, and the study of the chronicles according to guidelines set down by A. A. Shakhmatov-resulted in a broader application of the concept of feudalism to Russian history, and finally its application even to the Kievan period. ${ }^{6}$ This line of development energed completely in 1932 when B. D. Grekov provicled the classical formulation. Marxist historians adopted Grekov's thesis that Kievan Rus' had been essentially feudal and that Russia had bypassed the slave owning stage of social evolution. His thesis became the basis of the system of views that replaced Pokrovskii's. For the non-Marxist historian, this period was the final glow of the silver age of Russian culture.

A major center of non-Marxist scholarship was the Academy of Sciences in Leningrad, ${ }^{7}$ where the Historico-Philological Department contained a number of research organizations including the Permanent Historico-Archeographic Commission, ${ }^{8}$ the Russian-Byzantine Commission, and the Paleographic Museum. These bodies had resources only for archival work, while research and training were carried out in GAIMK (State Academy for the History of Material Culture). Although the Institute was founded in 1919 on the remains of the Academy of Sciences' Archaeological Commission, it was formally independent of the Acadeny by decision of Communist authorities. ${ }^{9}$ In 1927, it was brought within the framework of RANION. ${ }^{10}$

5. E. Maksimovich, "Istoricheskaia nauka v SSSR i marksizm-leninizm," Souremennye zapiski, no. 62 (1936), p. 415; see also S. P. Mel'gunov, Vospominaniia i dncrniki, 2nd ed. (part 3) (Paris, 1964), pp. 81-82; and M. M. Novikov, Ot Moskvy do N'iuIorka: Moia zhiz⿲' $v$ naukc i politikc (New York, 1925), pp. 324-28.

6. See I. Trotskii, "Osnovnye voprosy drevnei russkoi istorii v literature poslednikh let," Istorik-marksist, no. 8 (1928), pp. 182-91; and V. P. Volgin, E. V. Tarle, A. M. Pankratova, eds., Dvadtsat'piat' let istoricheskoi nauki v SSSR (Moscow, 1942), pp. 91104.

7. For a concise, informative description see S. F. Platonov, "Istoriia," in Akademiia nauk SSSR za 10 lot, 1917-1927 (Leningrad, 1927).

8. Formed by the amalgamation of the Academy's Permanent Historical Commission, founded in 1903, and the Archeographic Commission of the Ministry of Education, founded in 1834. p. 42.

9. O. L. Vainshtein, Istoriia suvetskoi medicvistiki, 1917-1966 (Leningrad, 1968),

10. D. A. Magerovskii, "Rossiiskaia assotsiatsiia nauchno-issledovatel'skikh institutov obshchestvennykh nauk," Nauchnyi rabotnik, 1927, no. 11, p. 56. For a personal account of the Academy that brings out many of the distinctive features of the evolution of historiography in Leningrad, see the essay of S. N. Valk dedicated to I. I. Smirnov in Krest'ianstvo i klassovaia bor'ba v' feodal'noi Rossii, Trudy Instituta Istorii, Leningradskoe Otdelenie, vol. 9 (Leningrad, 1967), pp. 5-41. 
RANION (Russian Association of Social Science Institutes) was an assembly of fourteen research and teaching institutes organized and directed, until 1927, by Pokrovskii. ${ }^{11}$ Whereas the Institute of Red Professors had been created to provide propagandists, instructors, and scholars for party assignment, RANION's institutes were created to provide Marxist instructors and scholars for the national education system. No doubt both fiscal and political considerations caused authorities to centralize graduate training. The institutes of RANION were a principal manifestation of the policy of "using non-communist hands in the building of communism." They were centers of non-Marxist scholarship. However, because, unlike the students, only a minority of the staff were Marxists, RANION as a whole should be thought of as a semi-Marxist institution.

RANION's Institute of History was created in 1921 by official decree. A year later some members of the Commissariat of Education, anxious about the influence of non-Marxists, urged abolition of the Institute, but their arguments were rejected on the authority of Pokrovskii and of V. P. Volgin, an academically trained Marxist historian and an ex-Menshevik. The Institute was attached to the Social Sciences Faculty (FON) of Moscow University in 1922. In 1923, the Communists established a majority in the Presidium of FON and in colleges of individual institutes within FON. Two years later the Institute of History was transferred to RANION and became a graduate center. At this time; a "communist nucleus" was also established. ${ }^{12}$ In 1927, a branch of the Institute of History was opened in Leningrad.

The Institute's structure reflected its semi-Marxist character. It contained sections with the traditional designations of ancient, medieval, and modern history, but new sections were created which reflected Marxist preferences: a section for the study of non-European societies and colonial politics, and a subsection on Russia in the era of the revolutionary movement and the Communist Party. ${ }^{13}$

11. Magerovskii, Nauclnyi rabotnik, 1927, no. 11, p. 56; the Association had 412 members and 311 research associates, p. 53.

12. See Ivanova, Istoriia SSSR, 1960, no. 6, p. 66; Vestnik Kommunisticheskoi akademii, no. 26 (1928), p. 257; Istorik-marksist, no. 5 (1927), p. 276.

13. The same hybrid character was reflected in the composition of the staff. The Marxist component included Pokrovskii, D. Riazanov, and V. Nevskii, an old Bolshevik, trained as a chemist, who had played an important part in the October Revolution. In the earlier 1920s as head of the Leningrad Istpart, he had sided with Zinoviev. In the mid-1920s he was brought to Moscow as head of the Lenin Library. He was a recognized authority on party history. N. Vanag and A. Pankratova were IKP graduates beginning their pedagogical careers. The non-Marxists included A. Presniakov, E. Tarle, M. Bogoslovskii, M. Liubavskii, V. Picheta, and P. Preobrazhenskii. S. Skazkin was among the senior collaborators, and N. Druzhinin and B. Kafengaus were among the junior collaborators. Its graduates included V. Khvostov, B. Porshnev, A. Neusykhin, A. Erusalimskii, L. Cherepnin, A. Artsikhovskii, M. Nechkina, and S. Nikitin. 
The Institute represented an uneasy compromise that could be considered icleal only from the students' point of view. ${ }^{14}$ According to $T$ s. Fridliand, one of Pokrovskii's chief lieutenants, the Institute "assembled within its walls all that remained of old bourgeois scholarship." "Maximum freedom for scientific activity" was established there for "all those old luminaries." Even those who "on principle did not wish to work at the Institute of Red Professors were permitted to work in RANION."15 Consequently, RANION's Institute of History, conceived to complement the Institute of Red Professors, soon becane its rival. Moreover, to the degree that the Institute of History informally constituted a "voluntary tribune," it also rivaled the Society of Marxist Historians. Thus, even though the nonMarxists were accorded little independence and security, they were still a constant source of anxiety to the regime.

The dualism in Soviet scholarly institutions was extremely sensitive to political change. The demise of the NEP and Stalin's ascent to power during the First Five-Year Plan influenced academic practices as well as social arrangements. Stalin's efforts alienated Bukharin and crystallized the Right Opposition, but he outmaneuvered and overwhelmed his opponents. Circumstances necessitated a new line, and the state and party organs adopted the assumptions underlying Stalin's policies. ${ }^{10}$ The Shakhty Trial in spring 1928 -conviction of foreign and native technical specialists on trumped-up charges of wrecking-was a major step in the formulation and implementation of the new policy. Stalin followed through with a purge of the state apparatus and the trade unions, ${ }^{17}$ and he pushed the new line through the Comintern as well.

The struggle between Stalin and Bukharin had its first direct reflection among historians as early as 1927 , when a brief skirnish, probably a reconnoitering action on the part of Stalin's followers, occurred within the walls of RANION. An article appeared in the newspaper, Evening Moscow, ${ }^{18}$ complaining about "de-Marxification" of the Institute of History and resurgence of the old scholarship. The rarticle quoted a student wall newspaper: "... in our institutes, at some meetings of various sections, the name of

14. For a vivid description by a former student, see A. S. Nifontov, "Iz opyta nauchnoi raboty istorika," Istoriia SSSR, 1963, no. 2, pp. 118-40.

15. Ts. Fridliand, "Ob ideologicheskoi bor'be na istoricheskom fronte," Kommunisticheskaia revoliutsiia, 1928, nos. 23-24, p. 30.

16. See N. Popov, Outline History of the Communist Party of the Soviet Union, 2 vols. (Moscow-Leningrad, 1934), 2:369.

17. Ibid., p. 376.

18. "V chem delo, kak podgotovliaetsia nauchnaia smena (za kulisami RANIONa)," Vcchcrniaia Moskva, February 6, 1928. 
Marx and even more so the name of Lenin is subjected, as in Tsarist Russia, to zoitticism." In a similar vein, it was pointed out that although Marx's name was "taboo," it was fashionable for professors to cite bourgeois authors like Sombart and Weber, whose plagiarisms and falsifications of Marxism were taken "as the latest 'discoveries' of science." Shortly after the appearance of the article in Evening Moscoze, a student delegation visited Pokrovskii's office and demanded that the situation be remedied. A review of personnel resulted in the expulsion of almost 10 percent of the students. ${ }^{19}$ Some of the Marxist professors found themselves accused of defending non-Marxist colleagues by depicting the students' campaign as ultra-left deviationism and as baiting the specialists. Fridliand derided the Marxist professors for "taking pride in being accepted in the midst" of non-Marxists as " 'tame' communists."20

Perhaps these events were merely heat lightning following the Fifteenth Congress of the Communist Party, accompanying the food shortage and forcible grain collections. On the other hand, the students' demands so closely anticipated Stalin's personnel policies later in the year, that one is led to believe the events were contrived. The criticism of non-Marxist professors may have been a tactical experiment by Stalin's followers, a move to state in Stalinist terms the issues that separated Marxists from non-Marxists. At any rate, as late as August 1928, RANION was mentioned in a Central Committee resolution as an adjunct of party schools. ${ }^{21}$

A more serious but even more heavily-veiled conflict occurred in the Institute of Red Professors early in 1928, when a struggle for control of the party cell of the Institute broke out. N. A. Uglanov, secretary of the Moscow branch of the party, had in February, according to his Stalinist accusers, used the Institute's party cell to state the Right Opposition's views on industrialization and grain collections. Criticism from rank and file party members in the Institute ensued in March, apparently resulting in a change of personnel in the party bureau. ${ }^{22}$ Uglanov's loss of the Institute as a platform marks an early victory for Stalin's supporters over the Right Opposition.

Criticism of non-Marxist historians intensified after the change of leadership in the Institute of Red Professors. Late in March, random polenics were replaced by a campaign of criticism, but Stalin's new line stressing class conflict and foreign intervention did not win the field entirely. Opposition was encountered at a conference on "problems of agitation, propaganda, and cul-

19. Ivanova, Istoriia SSSR, 1960, no. 6, p. 69; see also O. L. Vainshtein, "Stanovlenie sovetskoi istoricheskoi nauki (20-e gody)," Voprosy istorii, 1966, no. 7, pp. 32-47.

20. Fridliand, Kommunisticheskaia revolintsiia, 1928, nos. 23-24, pp. 29-30.

21. Izvestiia Ts. $K V K P(b)$, September 10, 1928, p. 9.

22. V. Zeimal', P. Pospelov, "Iacheika IKP v bor'be za general'nuiu liniiu partii," Pravda, December 1, 1931. 
tural construction," sponsored by the Agitation and Propaganda Department (Agitprop) of the Central Committee in late May 1928. ${ }^{23}$ A. I. Krinitskii, an Agitprop staff member and the apparent organizer of the conference, invited representatives from a large number of institutions. ${ }^{24}$ The theme of his opening report was the alleged campaign against Soviet power by the non-Marxist intelligentsia. The thesis did not find full acceptance. The most forthright opposition came from A. V. Lunacharskii, commissar of education, who had been called to the conference to answer charges that a rightist danger existed in his Commissariat. Such charges, in this context, suggested temporizing or a conciliatory attitude toward non-Marxist intellectuals. According to A. I. Stetskii, ${ }^{25}$ future head of Agitprop, Lunacharskii denied the charges without providing any facts or arguments. But Lunacharskii stood his ground although his clenial angered Stetskii and others. Quoting Bukharin, Lunacharskii argued that the very concept of leaps forward was senseless when talking about cultural and educational policy. ${ }^{26}$

What were the lessons to be learned from the Shakhty affair and related events? Was it evidence of a conspiracy by the bourgeois -intelligentsia or by the right wing of the party, or did it merely show the need to educate a greater number of political cadres-for closer ties with and greater activization of the masses, and for the strengthening of intraparty democracy? Conflict over this point survived the conference and persisted even after the July plenum of the Central Committee. According to a resolution of the Agitprop Conference:

In conditions of intensifying ideological conflict, of successful advance of Marxism-Leninism and an attempt at a counterattack by bourgeois theory, it is necessary to strengthen the guiding influence and leaclership of the party in all intellectual endeavor and scientific work of the country, to raise the organizational level, the degree of coordination and planning in the work of communist scholars and those nonMarxist scholars close to the party, for the purpose of maximizing the

23. The protocol of this conference has been published in Iz matcrialov $V$ sesoiusnogo soveshchaniia pri $T s . K V K P(b)$ po zoprosam agitatsii, propagandy i kulturnogo stroitel'stua (Moscow, 1928), and is available at the Lenin Library, but not for reproduction. Many of the issues of Kommunisticheskaia revoliutsiia for 1928 carry announcements, reports, and summaries of the conference. A portion of the resolutions has been reproduced in KPSS o kul'ture, prosveshchenii i nauke: Sbornik dokumentov (Moscow, 1963), pp. 445-46.

24. Including representatives of Commissariats of Education of Union Republics, cultural departments of trade unions, publishers, political organs of the Red Army, local Komsomols, the Women's Committee, and chairmen of leading central organizations. Kommunisticheskaia revoliutsiia, 1928, no. 1, pp. 96-97.

25. Ibid., 1928, nos. 11-12, pp. 180-82.

26. Ibid., pp. 174-77. 
productive application of their skills. In this the Comacadenny [KA] . . . should assure the hegemony of Marxist-Leninist theory. ${ }^{27}$

But the same issue of Kommunisticheskaia revoliutsiia that carried the summary of the Conference also published a Central Committee statement which provided a different answer by reiterating the need "to assure freedom of intraparty criticism that will root out the sorts of methods that destroy independent thought and negative appraisals by dismissing them out of hand as 'deviation,' 'rowdiness,' and so forth."'28

Criticism of non-Marxist scholars abated in the summer of 1928 when joint. Marxist-non-Marxist delegations attended historical meetings in Berlin and Oslo. In the activities of the delegations, however, one can perceive a reflection of the conflict manifested at the Agitprop Conference and further deterioration of the policy of "using non-communist hands in the building of communism." Upon invitation from the Society for the Study of Eastern Europe (Deutsche Gessellschaft zum Studium Osteuropas), a delegation of Soviet historians visited Berlin for the week of July 7-14, 1928. The Soviet delegation, headed by Pokrovskii, ${ }^{29}$ was greeted by a thirty-man committee that included Hans Delbrück and Edward and Henry Meyer.

The week consisted of banquets and conferences that coincided with the display of Soviet publications housed in the Prussian Academy of Sciences. At the opening reception attended by political and scholarly luminaries of the day, a message from the government, in the name of the Reich's chancellor, was presented. It was emphasized, "that Germany in the highest degree is interested in the publication of documents on the history of the World War, ..." N. N. Krestinskii, the plenipotentiary to Germany, made an address on the theme "German Scholars in Russian Historiography." Pokrovskii in his

27. KPSS o kul'ture, prosveshchenii i naukc, p. 445.

28. Kommunisticheskaia revoliutsiia, 1928, nos. 11-12, p. 5.

29. It included M. I. Iavorskii, V. V. Adoratskii, a specialist in philosophy and head of the Ienin Institute, E. B. Pashukanis, the leading legal theorist and a member of the higher councils of the Conmunist Academy, I. I. Mints, Pokrovskii's assistant and head of the party unit at the IKP, S. M. Dubrovskii, one of Pokrovskii's most talented students at the IKP, and V. A. Iurinets, a Ukrainian philosopher who had studied under Deborin and Pokrovskii. The non-Marxist component of the delegation consisted of V. I. Picheta, a specialist in the history of the Slavs, S. F. Platonov, a well-known non-Marxist historian and head of the Historico-Philological Department of the Academy of Sciences, M. K. Liubavskii, a former rector of Moscow University, and D. N. Egorov, a specialist on European feudalism. German scientists had prepared a similar reception the previous year for Soviet scientists. I. I. Mints, "Marksisty na istoricheskoi nedele v Bcrline i VI istoricheskom Kongresse istorikov v Norvegii," Istorik-marksist, no. 9 (1928), p1). 84-85, 88; E. B. Pashukanis, "Nedelia sovetskikh istorikov v Berline," Vestnik Kommumisticheskoi akadcmii, no. 30 (1929), pp. 238, 240, 242; see also Konstantin F. Shteppa, Russian Historians and the Soviet State (New Brunswick, 1963), p. 43. 
opening remarks "rejected the assertion that in Russia only Marxists were allowed to carry out scholarly activities." 30

At a subsequent meeting Pokrovskii read a paper on the "Origins of Autocracy." S. F. Platonov presented his findings on the study of the Russian north. Characteristically he stressed the importance of merchant capital in the development of the region. Protestations of tolerance seemed to be the watchword of the Soviet clelegation. Responding to a gibe by Edward Meyer, Pokrovskii is reported to have asserted that "the Marxist conception bears the imprint of achievements of historical scholarship, the authors of which are by no means Marxists," and "the strength of Marxism lies precisely in the fact that scholars who are not Marxists but simply good historians, conscientiously studying the facts, arrived at conclusions, affirmed by Marxist theory." 31

Professor Halvdan Koht, presiclent of the Norwegian Academy of Sciences, chairman of the Organization Committee of the Congress, and chairman of the Congress, had invited the Soviet delegation to the Congress. ${ }^{32}$ (According to Pokrovskii, Koht "considered himself to be a Marxist.") Pokrovskii was grateful for the invitation, but in a report to the Presidium of the Communist Academy he complained about the unpreparedness of the Soviet delegation-although the Polish contingent had fifty members, and the French one hundred, the Soviet delegation counted only eleven. Pokrovskii tried to arrange to have a Soviet delegate present at each session, and almost all the Soviet historians had written papers. However, Pokrovskii complained that in discussion the Soviet clelegates were usually silent: "I spoke twice, but I must say-not forcefully, and others were silent altogether." Some of the papers read by the Soviet Marxists aroused interest and attracted young people to the sessions, but the Russians spoke German so badly that they

30. Pashukanis, Vestnik Kommunisticheskoi akadcmii, no. 30 (1929), pp. 238-40; Mints, Istorik-marksist, no. 9 (1928), p. 87.

31. Pashukanis, Vestnik Kommumisticheskoi akademii, no. 30 (1929), pp. 242-43.

32. The delegation of thirteen Soviet historians consisted mostly of holdovers from the Berlin week. Platonov, however, had been dropped. There were in fact no members of the Academy of Sciences at the Congress. Tarle had been included in the delegation but reportedly fell ill in Paris. Hrushchevskii, the eminent Ukrainian historian, was also a member of the delegation, and like Tarle he failed to appear. Tarle was scheduled to represent the Academy of Sciences. It may be that he fell ill in Paris or that he, along with Platonov and others, was denied permission to attend. See Pokrovskii, "O poezdke v Oslo," Vestnik Kommunistichcskoi akadsmii, no. 30 (1929), p. 236 and Shteppa, Russian Ifistorians and the Sovict State. p. 43. There is a curious discrepancy in reports of the composition of the delegation. Mints, who was not a member, but who accompanied it, includes M. I. Iavorskii, the prominent Ukrainian Marxist historian. Istorik-marksist, no. 9 (1928). According to O. V. Treskova, editor of some recently published documents, Iavorskii was dropped and A. E. Presniakov, one of the best known non-Marxist historians of Russia, was included. "Dokumenty ob uchastii sovetskikh uchenykh v VI Mezhdunarodnom Kongresse istoricheskikh nauk," Sovetskie arkhivy, 1973, no. 6, p. 53. 
could not even understand each other. As a result, the meetings usually were adjourned without discussion. ${ }^{33}$

To make matters worse, the non-Marxist members of the Soviet delegation conversed freely with others. It was, in fact, comments made by Professor B. L. Bogaevskii to M. I. Rostovtsev, the prominent historian of antiquity who had emigrated from Russia during the Civil War and was present in Oslo as a member of the American delegation, that finally served to dramatize the Soviet presence. When Pokrovskii was elected to the Presidium of the Congress, Rostovtsev registered a complaint with reporters of the local press. As retold by Pokrovskii, Rostovtsev complained that Pokrovskii was "not a scholar at all, but a destroyer of Christian faith, a wrecker of higher education and higher schools in Russia, and that a Marxist cannot be a scholar, for Marxism is a dogma that contradicts freedom of research and that there can be no scholars in Russia, etc." Professor Koht disavowed Rostovtsev's remarks in the name of the Congress, and Pokrovskii held an interview that also made the front page. In a speech at the closing banquet, Rostovtsev chose not to resume the exchange. Yet Pokrovskii was infuriated and throughout the remainder of his life would allude to the Oslo Congress as a manifestation of class conflict on an international level. In reporting to the Communist Academy Presidium, however, Pokrovskii boasted that Rostovtsev had done the small Soviet delegation a "great service." He made it the object of attention. "We enjoyed a certain popularity." 34

After the Congress in Oslo, Pokrovskii incorporated into his pronouncements Stalin's assumption that a conspiracy between imperialists abroad and bourgeois elements within-kulaks and members of the old intelligentsiahad become active against Soviet power. Thus, he helped fashion the rhetoric that would reach its nadir in the purges. In the issue of Pravda celebrating the eleventh anniversary of the October Revolution, he published an article entitled: "Class Struggle on the Ideological Front":

Those anti-Marxist actions here in the USSR, the struggle with which some comrades are inclined to view as superfluous, even as a luxury, embrace only a part of the ideological front. [Its] base is not even in that class conflict which is being played out within the limits of our Union. Of course, if there had not been such a struggle, the corresponding "tendencies" would not have been able to find here a suitable environment; that's true, but our local conditions scarcely suffice [to explain] the appearance of independent anti-Marxism. The battle pro-

33. M. N. Pokrovskii, "Doklad o poezdke v Oslo," Vestnik Kommunisticheskoi akadcmiii, no. 30 (1929), pp. 231-37.

34. Ibid., p. 234; for some of the relevant statements, see also Samuel N. Harper, "A Communist View of Historical Studies," Joumal of Modern History, 1, no. 1 (March 1929) : 77-86. 
ceeds along an international front, and our side is obligated to use the historians of the USSR in support of our allies on a world-wide scale.

He concluded:

You can be assured that if that non-Marxist specialist sees before himself, not soft porridge but a firmly united front, he will recall immediately that even his grandfather in 1800 was a Marxist. ${ }^{35}$

Marxist historians searched out enemies on various sectors of the historical front in 1928. Medievalist D. M. Petrushevskii, chairman of RANION's Institute of History, bore the brunt of a spring campaign. Academicians E. V. Tarle, a prominent specialist in modern European history, and S. A. Zhebelev, a historian of antiquity, found themselves under attack in the autumn, as the Marxists' campaign became increasingly less scholarly and more public.

The discussion of Petrushevskii centered on his most recent book, Outlines of the Economic History of Medieval Europe, ${ }^{36}$ which had gained notoriety through an unfavorable review by Fridliand. ${ }^{37}$ At meetings on March 30 and April 6, 1928, the Society of Marxist Historians sponsored a number of reports and discussions related to the volume. The discussions were ill-tempered and unfair, yet touched upon important methodological problems and initiated a debate that, over a period of years, refashioned the theory of historical materialism. ${ }^{38}$

Critics charged that Petrushevskii's book was an example of bourgeois idealism. Petrushevskii, they alleged, had taken over the methods of Alphonse Dopsch, the Austrian medievalist, and had, consequently, assimilated the doctrines of Max Weber ${ }^{39}$ Most of the participants in the discussion seemed to

35. "Klassovaia bor'ba i ideologicheskii front," Pravda, November 7, 1928.

36. Ocherki iz ckonomicheskoi istorii srednevckovoi Evropy (Moscow, 1928). Dmitrii Moiseevich Petrushevskii (1863-1942) was a renowned specialist in European history-his chief specialty was English feudalism. He graduated from Kiev University and wrote his dissertation under the direction of P. G. Vinogradov in Moscow, a professor in the Kafedra of World History of Imperial Moscow University from 1906. He resigned in 1911 in protest against policies of the Ministry of Education. For an appreciation, see E. A. Kosminskii, ed., Srednyc vcka: Sbornik. Posviashchactsia pamiati akademika D. M. Petrushevskogo (Moscow-Leningrad, 1946).

37. "Dva shaga nazad," Pod znamcnem marksizma, 1928, no. 2, pp. 147-61. 79-129.

38. "Disput o knige D. M. Petrushevskogo," Istorik-marksist, no. 8 (1928), pp.

39. Just a year before the campaign now being treated, Istorik-marksist reported that a paper on Dopsch had been delivered in Leningrad under the auspices of RANION. L. V. Cherepnin, then a student at the Institute of History, presented Dopsch's hypothesis concerning Charlemagne's Capitulare de Villis. The report noted that a lively discussion ensued (no. 6 [1927], p. 299). 
be conversant with and anxious about the theories of Weber. (In view of the fact that Soviet scholars held German scholarship in high esteem, following it closely and reviewing it extensively, it is likely that Weber enjoyed a certain vogue.) A considerable amount of time was devoted to expounding the notion of "ideal type," apparently with the purpose of unmasking Petrushevskii and demonstrating that he had employed a "bourgeois" concept. According to A. D. Udal'tsov, a professor at the Institute of History, the doctrines of Max Weber represented an attempt by the bourgeoisie to formulate a world view and systematic methodology with the hope of stopping "creeping empiricism." To Stanislav Krivtsov, a former Bogdanovite who had become a party propagandist, such constructs, which exist outside time and space, represented a reformulation and application of Kantian ontology and ethics to social phenomena. In his view, both the categorical imperative, and the ideal type were commands from a world outside the realm of phenomena, a complex of values arrived at by "disciplined, trained fantasy." Krivtsov also pointed out that Weber's principles were closely related to Rickert's teachings: A historian "does not evaluate phenomena, but the relations thereof to definite cultural values." This concern with values revealed the subjective aspect of Weber's theory. Further, Krivtsov argued that if an objective basis for values cannot be established, then any law is valid, any standpoint as good as any other. The theory thus devolves into a pluralistic, multi-factor explanation. Yet not quite any standpoint is valid. An ideal type cannot embody just any set of values, but only those "alleged to be generally accepted." Attempts to formulate what values are "generally accepted" reveal the "wholly subjective character" of the theory. ${ }^{40}$

Krivtsov's implied conclusion was obvious to his listeners: The theory is subjective because there are no "generally accepted values." All values are historically existent and express the interests of particular social classes. In the case of Weber, the values are the traditional ones of bourgeois society.

E. A. Kosminskii and A. I. Neusykhin defended Petrushevskii, with whom they had studied at the Institute of History, contending that the discussion misrepresented the book. Kosminskii denied that the book was directed against Marxism and that it was a rehash of Dopsch. On the contrary, he argued, it drew on many authors and represented a highly original synthesis. Neusykhin argued that while Dopsch stressed the similarity between patrimonial and modern capitalism, it was precisely this analogy that Petrushevskii rejected. ${ }^{41}$ This defense managed only to provoke Fridliand and reinforced his conviction that Petrushevskii's book was less a work of scholarship than a political demonstration. Concerning Petrushevskii, Fridliand said:

40. Ibid., no. 8 (1928), pp. 81-82, 95.

41. Ibid., pp. 91 and 101. 
I would not say that this revolution in the views of Professor Petrushevskii is only his individual revolution. I would say that this is the logical style of bourgeois methodology .. . during the entire postwar epoch. ... It proves that many of our best professors cannot tear themselves from the grip of anti-Marxist schemata.

And for the self-styled Marxists and fellow-travelers, he gave warning:

I must note that the saddest thing in our discussion is that we are all bound to Marxism; this is suspicious. Our task is to unmask such people who call themselves Marxists. We consider the affirmation by comrade Neusykhin-that he [Neusykhin] is to any degree a Marxist-a misunclerstanding. . . They wish to depict us as barbarians desiring to attack science in the name of Marxism. No! We shall carry on an intense struggle against the barbarian attack on Marxism on the part of the fashionable Western-European schools of philosophy and their Russian pupils. We shall strive so that in the USSR the old custom of bringing to Russian soil the newest, most fashionable, latest word . . . as a new discovery, a new "interpretation of Marxism" will be forsaken .... ${ }^{42}$

Despite the trial-like atmosphere of the two meetings, they were an important event in Soviet intellectual history-a direct confrontation between Soviet Marxism and twentieth-century Western social theory. ${ }^{43}$ Although, on the surface, it appeared that Western theory was dismissed entirely, a genuine encounter did, in fact, occur. The nascent influence of Weber was one of the factors that compelled Soviet historians to review and recast the tenets of historical materialism. The new theory was, in part, a polemic against Max Weber. In this way, Weber posed some of the problems that Soviet historians sought to resolve from their own premises. The term "socioeconomic formation," for example, energed in subsequent discussions in the early 1930s as a rival to Weber's concept of "icleal type."

Pokrovskii had been slow to participate in the polenic against Petrushevskii, but speaking near the end of the second session, he denounced Petrushevskii in superficial, yet caustic remarks. Interestingly, just before the discussions, when Petrushevskii's book had already attracted unfavorable attention, Pokrovskii had obliquely defended him. Now, Pokrovskii told the conference that Petrushevskii's book revealed a loss of scholarly ability. Pokrovskii, however, also stated that Petrushevskii's students ("young historians, who have mastered Petrushevskii's technique"), "approach us ideologically, because they are full-blooded people." 44 In this way, Pokrovskii

42. Ibid., pp. $86,90,126,127-28$.

43. See I. M. Kushner's attempt to define the term socioeconomic formation, and to counterpoise his definition to the concept of the ideal type (ibid., pp. 105-6).

44. Vestnik Kommunisticheskoi akademii, no. 26 (1928), p. 267. 
stressed Petrushevskii's performance as a teacher and affirmed his usefulness.

Pokrovskii, on the other hand, set the pace in the polemics against Tarle. He censured Tarle's most recent book, Europe in the Epoch of Imperialism, ${ }^{45}$ for underestimating the importance of class struggle in the half-century before the World War and for attributing the war's outbreak primarily to German policy ("ententophilism"). ${ }^{46}$ To Fridliand, the book was a perfect example of "mimicry of Marxism," because Tarle had declared and actually believed that "his entire book is based on the study of Lenin, on the studies of Communist Marxists of the epoch of imperialism." Tarle's book was also censured in a number of reviews and at a number of meetings. ${ }^{47}$

Tarle was genuinely surprised by the treatment accorded him by the Society of Marxist Historians. ${ }^{48}$ Granted an opportunity to defend himself on the pages of Istorik-marksist, Tarle sought to show that his understanding of modern history was essentially Marxist. He found the outbreak of the World War to be rooted in economic processes and class conflict. The chief underlying cause of the war was the "fact that in the working masses the disposition to check the strivings of imperialistic plunderers by every means was not sufficiently developed." 49 An editorial note in Istorik-marksist, nevertheless, dismissed his arguments as those of a class enemy. ${ }^{50}$

In another incident, Academician Zhebelev and ten other Soviet scholars accepted an invitation to contribute to a collection of articles sponsored and published by the Seminarium Kondakovianum, an organized group of Russian scholars residing in Prague. Two similar volumes had been published previously, and there had been no outcry. The third volume, dealing with archaeology and Byzantine art, was no more political than the other two, but it provoked a harsh reaction, probably because its appearance coincided with an intense campaign to influence the election of new members to the Academy of Sciences. (Soviet authorities were in the process of revamping and reforming the Academy in accord with their own principles of scientific planning.) A lesser but still significant reason for the outcry was, undoubtedly, the fact

45. E. V. Tarle, Evropa $v$ cpokhu imperializma (Moscow, 1927). A second enlarged edition appeared in 1928.

46. The remarks were combined with comments on Petrushevskii and published as a lead article, "Novye techeniia v russkoi istoricheskoi literature," Istorik-marksist, no. 7 (1928), pp. 3-17.

47. Istorik-marksist, no. 9 (1928), p. 108; no. 13 (1929), pp. 235-38, 276. At a discussion in Leningrad, some students defended the book, and then the discussion itself became the subject of a brief controversy at the First All-Union Conference of Marxist Historians. The Leningraders succeeded in convincing the Muscovites that no Marxists had been among Tarle's defenders. See Trudy pervoi vsesoiuznoi konferentsii istorikov marksistov, vol. 1 (1930), p. 49.

48. Fridliand, Kommunisticheskaia revoliutsiia, 1928, nos. 23-24, p. 27.

49. "K voprosu o nachale voiny," Istorik-marksist, no. 9 (1928), p. 101.

50. Ibid., pp. 108-9. 
that M. I. Rostovtsev, antagonist of the Soviet delegation at Oslo, was also a contributor to the volume.

Zhebelev and his associates were attacked first in Leningrad. Shortly thereafter, I. K. Luppol, a professional philosopher and commentator on trends in the scholarly community, denounced the work in a public speech in Moscow's House of Scholars. On November 22, 1928, the Presidium of the Acaclemy resisted a call for Zhebelev's resignation, but Zhebelev, nevertheless, deemed it appropriate that he apologize publicly for remarks he had made in the introduction to the volume. ${ }^{51}$

The First All-Union Conference of Marxist Historians, held December 28, 1928 through January 4, 1929, was a vehicle for demonstrating the maturity of Marxist scholarship and for creating a united front against the non-Marxist rivals. The climax of the conference, in some respects the climax of the entire campaign against non-Marxist scholarship, was Pokrovskii's decision to support a proposal to liquidate RANION's Institute of History and to replace it with a new institute that would be a component of the Communist Academy. ${ }^{52} \mathrm{His}$ decision coincided with the effort to bring the Academy of Sciences under the sway of Soviet authority.

Although the autonomy of the Academy of Sciences had begun to erode in the early years of the Soviet regime, government authorities took a crucial formal step in June 1927 with a new charter that impaired the right of the Academy to nominate its own members. This allowed the Communists to nominate nine members in 1929, including Bukharin, Pokrovskii, N. M. Lukin (a specialist in modern European history and a close associate of Pokrovskii), V. M. Friche (a Marxist literary critic), and A. M. Deborin (a former Menshevik who was now head of the Communist Academy's Institute of Philosophy). In the public discussions, all of the Communist nominees were approved, but in the elections, which were closed meetings, threeDeborin, Friche, and Lukin-were rejected. All non-Marxist candidates, including Petrushevskii, were approved. ${ }^{53}$

51. I. K. Luppol, "Ob otnoshenii sovetskikh uchenykh $k$ uchenym emigratsii," Nauchnyi rabotnik, 1928, no. 12, pp. 13-22, and the Chronicle of the same issue, pp. 111-14. For further information and additional references, see Loren R. Graham, The Soviet Acadcmy of Scicnces and the Communist Party, 1927-1932 (Princeton, 1967), pp. 104-8, and L. Hamilton Rhinelander, "Exiled Russian Scholars in Prague: The Kondakov Seminar and Institute," Canadian Slavonic Papcrs, 16, no. 3 (1974): 331-52. Zhebelev himself fared well subsequently and continued his work in the Academy of Sciences. During the siege of Leningrad, he had the responsibility of preserving the local buildings of the Academy. He perished in the siege.

52. For details see my article, "M. N. Pokrovskii as an Organizer of Scholarship," Jahrbiicher für Geschichte Osteuropas, 22 (1974): 56-67.

53. Pravda, January 25, 1929; I. K. Luppol, "K vyboram v akademii nauk SSSR," Nauchnyi rabotnik, 1928, no. 11, pp. 3-4; Shteppa, Russian Historians and the Soviet State, p. 48. 
Pravda interpreted the elections as "a political demonstration against the working class," and initiated a campaign against the old academicians. The campaign can be followed on the pages of Pravda in late January and early February 1929. Letters appeared from almost all party-led scholarly institutions-even the nonparty workers of the Red Triangle Factory protested-all to the effect that "the Academy should cease being a state within a state." Finally, on February 8, the Presidium of the Academy capitulated, announcing that new elections would be held in the near future. ${ }^{54}$ In the summer, the sporadic campaign to discredit non-Marxist scholars resumed and continued through the fall. Pravda reported that sixty-one research workers had been removed in the course of a purge not quite half completed, the GPU announced it had uncovered a monarchist plot by former tsarist officers in Leningrad,55 and Professor Rozhdestvenskii, a Leningrad historian, was arrested. ${ }^{56}$ In November, the press accused some of the academicians of concealing documents of historical significance and not cooperating with the government purgers. At an open meeting a few days later, speakers denounced the accused as Black Hundreds. As a result, S. F. Ol'denlurg lost his post as permanent secretary of the Academy and S. F. Platonov was removed as head of the Academy's library. ${ }^{57}$

Some of the non-Marxists, including B. E. Grekov, N. Ia. Marr, S. B. Veselovskii, and S. V. Iushkov, ${ }^{58}$ underwent conversions and succeeded in insinuating themselves into the rival camp. Others were arrested and were involved in the show trials of the era. Tarle fell victim in the Industrial-Party Trial in 1930 and was exiled to Central Asia. ${ }^{59}$ Numerous historians were

54. Pravda, January 25, 1929; February 1, 1929; February 9, 1929. For a more complete account, see Loren Graham. The Sozict Acadcmy of Sciences and the Communist Party. 1927-1932, and Alexander Vucinich, The Sozict Acadcmy of Sciences (Stanford, 1956), pp. 21-41.

55. Pravda, September 20, 1929.

56. Shteppa, Russian Historians and the Sovict Statc, p. 49.

57. Pravda, November 16, 1929; November 19, 1929; Nauchnyi rahotuik, 1930, no. 1, p. 97. Ol'denburg had hitherto enjoyed considerable security. He had known Lenin's brother, Alexander. When Lenin first arrived in St. Petersburg, he sought out Ol'denburg to discuss with him Alexander's scientific work. See A. I. Ivanskii, ed., Molodyc gody V. I. Lenina: Po z'ospominaniiam souremennikov $i$ doknmentam, 2nd ed. (Moscow, 1958), pp. 389-90.

58. Shteppa, Russian Historians and the Sovict State, p. 49; see also E. F. Maksimovich, "Istoricheskaia nauka v SSSR i marksizm-leninizm," Sovremennyc zapiski, no. 62 (1936), pp. 417-18; "The Treatment of Scholars in the U.S.S.R.," Slavonic and East Europcan Reviczo, 11 (1933): 710-14; Vestnik Kommunistichcskoi akadcmii. no. 32 (1929), p. 229. Naidenov, Istoriia SSSR, 1961, no. 1, p. 92.

59. Sotsialisticheskii vestnik, no. 22 (1931), p. 15; Stuart Tompkins, "Trends in Communist Historical Thought," Slavonic and East Europcan Rezierc, 13 (1934): 308; G. Zaidel and M. Tsvibak, "Vreditel'stvo na istoricheskom fronte. Tarle, Platonov i ikh shkoly," Problcmy marksizma, 1931, no. 3, p. 96. Soviet historians usually remained silent about the arrests or referred to them obliquely; note the following statement by $F$. 
affected by the Academic Case (sometimes called the Platonov Case), which has been described by the émigré scholar, V. V. Tchernavin. ${ }^{60} \mathrm{~A}$ wave of arrests occurred throughout the two-year period after the purge of the Academy of Sciences. Charges of monarchist plots were issued, yet no confessions were published, no sentences were announced, and no trial was ever held. Some of the victims were shot, but most of then were sent to the camps. The more fortunate merely endured exile in remote provinces. In the 1930s, many historians were restored to society and resumed scholarly pursuits as self-professed Marxist historians. So ended non-Marxist historiography in Russia.

Throughout this academic purge of the late 1920s, Marxist historians sought to explain and justify the clemise of non-Marxist historiography. These explanations not only affected the events taking place, but also became working assumptions of Soviet historians. For example, Ts. Fridliand stated that the immediate cause was an offensive by the non-Marxist historians against Soviet power. This offensive was a response not only to the success of Marxist historiography but to the nationwide victories of socialist construction-the triumph of the party over the kulaks, nepmen, bourgeois and pettybourgeois intellectuals. Friclliand's hypothesis, however, was somewhat more complex than the bare suggestion that the bourgeoisie had gone on the offensive. He suggested that the crisis was exacerbated by the indecisiveness of the Marxist response. The activity of "pseudo-Marxists" would not have been dangerous had "communist-historians presented a united, well-knit front." Far from closing ranks, some of the Marxists resisted the decision to unmask Petrushevskii and Tarle. Some expressed opposition by remaining silent, and others openly attacked "extreme struggle" on the historical front. They accepted, according to Fridliand, the "slogan 'laissez-faire, laisser passer' [and felt that] the free play of forces would be the best exit from the present situation." One Communist, Fridliand alleged, even had declared "that the task of Marxism by no means consists of suppressing other points of view. 'Live and let live." ",61

Pokrovskii, casting about for justification, explored various lines of thought. While usually agreeing with Fridliand, some of Pokrovskii's remarks suggest a variant explanation which implicitly recognized that it was the

Potemkin, who was, like Tarle, a diplomatic historian: "Not only theoretical differences separate us now from Tarle, but-speaking without metaphor-thick walls with firm bars separate [us]," (Istorik-marksist, no. 21 [1931], p. 53). Pokrovskii, in March 1930, referred directly to a purge going on of historians in institutions of higher learning (ibid., no. 16 [1930], p. 16).

60. I Speak for the Silent Prisoners of the Sovicts, trans. N. M. Oushakoff (Boston and New York, 1935). See "Academic Case," pp. 359-68.

61. Kommmnisticheskaia rexoliutsia, 1928, nos. 23-24, pp. 23, 28-29, 31. 
Marxists who had gone on the offensive and which brought additional factors into account as well. The crux of Pokrovskii's position was that the older scholarship had outlived itself. It represented a corpse that needed to be shoved into the grave. "That which yesterday was considered science, today is no longer science, but in the best instance a certain preparation for science, a certain gathering of materials, etc." 62 What was science in 1910 ceased being science in 1920, but the change was not realized until 1928. Yet the corpse continued to stir and had developed a voracious appetite. "No "No matter what the situation was," Pokrovskii observed in 1929, "a new generation is now present. This must not be forgotten for a moment." Henceforth, scholarship should consist of collective enterprises, and "frequently a conductor's baton will be required." Acknowledging that historical research institutes continue to be clominated by non-Marxists, Pokrovskii remarked:

The conductor's baton is held in the hands of the "worthies" themselves or those authorized by them, before whom stand long years of physically active life, but for whom the sumptuous marble memorials in the cemetery of ideology have long been ready. We have still not a single scientific institution in the field of history, where our scientific youth can feel . . . themselves at home and see around themselves in the capacity "of the older generation" only the elderly representatives of the ideology for which they struggle . . . ${ }^{64}$

Pokrovskii in effect argued that because the old scholarship presides, its representatives could set standards and determine relationships with the rest of society. The young Marxists, even though they were the genuine scholars, were deprived of authority. This was so despite the fact that they lived in a Marxist-proletarian state. A prerevolutionary situation existed, the non-Marxists governing and willy-nilly suppressing Marxism so that now an October Revolution in scholarship was necessary.

A. M. Pankratova, who participated in the events reviewed here, produced still another variant explanation. She viewed the destruction of nonMarxist historiography as a consequence of efforts by the party leadership to clear its own house of contraband theories. The "history and perspective of the proletarian revolution" became crucial matters "only when the party was involved in the struggle against Trotskyism." It fell to historians to underp. 3 .

62. "Institut istorii i zadlachi istorikov-marksistov," Istorik-marksist, no. 14 (1929),

63. Pokrovskii, ibicl., no. 14 (1929), p. 3. Pokrovskii's interpretation, with slight variations, has become the standard Soviet version. See M. Nechkina, Iu. Poliakov and L. Cherepnin, "Nekotorye voprosy istorii sovetskoi istoricheskoj naukj," Kommunist, no. 9 (June 1961), pp. 58-70. p. 6.

64. "Vsesoiuznaia konferentsiia istorikov-marksistov," Istorik-marksist, no. 11 (1929), 
take, "under the supervision of the party, a rebuff to the opportunistic revision of the Leninist teaching concerning the possibility of building socialism in our country." 65 This presumed affinity between Trotsky and the nonMarxists explained why, in Pankratova's opinion, historians had to go beyond "unmasking the Trotskyite schema." It was necessary to identify the ideological-political foundations of this schema with bourgeois and petty-bourgeois conceptions of the October Revolution. In the struggle against Trotskyism, Bolshevik historians conducted a struggle against the historical schema of the bourgeois restorationists and the petty-bourgeois liquidators. ${ }^{66}$ The "rebuff" the non-Marxists had to endure was, therefore, a by-product of intraparty conflict. Merely going about their business, the non-Marxists impinged on party prerogatives. Non-Marxist historiography proved to be an obstacle both to the long-range aspirations of socialist construction and to the immediate exigencies of state building.

The preceding survey of Soviet historiography raises many questions. Were many non-Marxist historians being drawn to the banner of Marxism? Were others using their pedagogical authority to instill a competing world view in their students? Were Marxist historians satisfied by their own efforts at historical construction? Is it possible to determine whether students and professors were becoming less or more ideologically-minded? More generally, were the party's cultural policies succeeding, and was the expectation that non-Communist hands could be employed in the building of communism being borne out by experience? Finally, were the forebodings expressed about a resurgence of non-Marxist historiography genuine or contrived?

A proper answer to the question of possible resurgence of non-Marxist historiography would require separate investigation, but the materials at hand for this study indicate that the answer would be negative. The allegation should not, however, be viewed merely as a contrivance of the Marxists. In the conflict between Marxist and non-Marxist historians, factors combined in a peculiar fashion. The growing strength of the Marxist historians manifested itself in their increasing numbers, enlarged resources, and effective organization, but the continued strength of the non-Marxists was also evident, for their influence persisted despite meager resources and the absence of autonomous organization. Few non-Marxists embraced the official creed, and, although no evidence of an offensive exists, the attitudes and methods of the non-Marxists did not evolve in the direction foretold by the Marxist theory of cultural revolution. This itself created anxiety in the Marxist camp.

65. "Novye problemy istoricheskoi nauki v SSSR," Vestnik Kommunisticheskoi akadcmii, no. 4 (1934), p. 69 .

66. Ibid., p. 70. 
On the other hand, expanding organizational power of the Marxist historians may well have engendered favorable sentiments about the old way of looking at things. The post-Civil War generation of scholars, no matter how pleased they might have been with Soviet power, could not easily duplicate the sense of commitment of the generation that had made the Revolution. Students, perhaps skeptical of a complete Marxist commitment, may have viewed non-Marxist historians-who were generally agreed to be the best trained and most accomplished among the teachers at the Institute of History-sympathetically as underdogs. It is possible that the dynamics of generational conflict, in at least some of its aspects, were working against the Marxists.

Under other circumstances, the persistence of non-Marxist historiography would not have resulted in its demise. One might suggest that the outcome of the conflict between Marxist and non-Marxist historians was determined by its context-the struggle for power within the party. Suppression of the opposition required not only "discrediting" their views, but the elaboration and inculcation by the victorious faction of a comprehensive, yet highly specific, view of the past. The new interpretation included both the specifics of party hagiography and a comprehensive reevaluation of Russian history in such fashion that would sanction the doctrine of "socialism in one country." In a broader sense, the new interpretation had to legitimize political authority by reaffirming the scientific character of Marxism; it had to prove that the outcome of the Revolution and the subsequent evolution of Soviet society were in accord with Lenin's prerevolutionary prognoses. The circumstances of party life gave rise to a new system of ideas, but developing and enforcing the new system required the suppression of all opposition, not merely of political opposition. In the course of this process historical writing became increasingly subordinated to the party line. 